\title{
Teacher and Technoloy: Christian Education Teacher Strategies in Implementing Online-Based Learning in Pandemic Times
}

\author{
Talizaro Tafonao ${ }^{1}$, Benteng Martua Mahuraja Purba² \\ Dosen Sekolah Tinggi Teologi REAL Batam ${ }^{1,2}$ \\ talizarotaf@sttrealbatam.ac.id ${ }^{1}$, bentzmm@sttrealbatam.ac.id ${ }^{2}$
}

Article History: Received: October 2, 2021; Accepted: November 28, 2021; Published: November 30, 2021

\begin{abstract}
The purpose of this research is to investigate the efficacy of teacher-led online teaching practices during pandemics. In this digital era, all teachers are required to adapt quickly to technological developments. But in reality, some Christian Education teachers are still not ready to transform in utilizing the application of technology as described in this article. Based on that question, the authors reviewed this topic to explain the essential steps teachers should take in implementing online-based learning strategies during pandemics. A descriptive qualitative research method was adopted in this work. The researchers gathered information through reading academic articles and books. The author analyses the data through analytical techniques by reducing, classifying, and verifying the study of this article. The results obtained in this study are very effective if Christian Education teachers apply online-based learning strategies in a way that teachers learn to provide features that are easily accessible to students. Teachers learn to design learning online, and teachers get used to providing stimulus to learners. Thus, online learning requires every teacher to adapt, innovate, and utilize digital media to facilitate the learning process during the pandemic.
\end{abstract}

Keywords: Christian Education, Online-based Learning, Pandemic, Teacher Strategies, Technology

\section{Copyright (C) 2021 The Author(s)}

This is an open access article under the CC BY-SA license.

\section{INTRODUCTION}

Since the emergence of COVID-19 in Indonesia, everyone has experienced fear, anxiety, and worry. As a result, all activities outside the home are restricted, including learning activities in school. Furthermore, based on the circular issued by the government quoted by Safitri et al. in Kompas.com, all indoor and outdoor activities are temporarily postponed to reduce the spread of corona, especially in education. (Safitri et al., 2020). Additionally, on March 24, 2020, the Republic's Minister of Education and Culture released Circular Letter No. 4 of 2020 on Education Policy in the Emergency Period of COVID-19 Spread. The circular says that online/distant learning is used to conduct the learning process at home.

Since the letter was issued, the learning process has been conducted online (online), utilizing smartphones, laptops, and internet networks. However, many pupils who are not 
Tafonao et al. | Teacher and Technoloy: Christian Education Teacher Strategies in Implementing OnlineBased Learning in Pandemic Times

accustomed to online education have trouble learning at school. According to Basar, many students complain about online learning, such as unstable internet networks, too many tasks, teachers who are always monotonous to teach, limited internet quotas, and most students who do not have personal devices (Basar, 2020). In addition to the above problems, in research conducted by Gumitri and Eliza, the longer students learn online will negatively influence students' learning achievement. One of the negative things he sees is that children wrongly use gadgets as a tool for learning but are more widely used to play games (Gumitri \& Eliza, 2021).

Furthermore, psychologically children experience stress because of the above problems; almost all children experience it. Utomo also observed that children felt depressed because of learning by being forced to independently without assistance from parents at home (Utomo et al., 2021). Christian Education teachers are responsible for paying attention to and preparing for learning during pandemics by looking at the above problems. One of the essential things that Christian Education teachers should do is to prepare for online-based education. This demand is not as easy as many people think so far; it turns out that learners experience online learning problems, but teachers also share the same thing. One of the complaints experienced by predominantly Christian Education teachers is the difficulty operating computers (technology) and accessing the less stable internet. A study conducted by Prawanti and Sumarni said it must be recognized that teachers do not all understand the use of online platforms in supporting online learning activities. As a result, many teachers rely on old methods such as lectures and giving tasks to learners (Prawanti \& Sumarni, 2020).

The author sees that the above problems should not be ignored; Christian Education teachers must transform the digital world and use the right strategies in teaching online. The duties and responsibilities of the Christian Education teacher are very complex and integrated into the learning he leads (Situmorang et al., 2019). Still, he must have the right and good strategy. In general, strategy has an understanding as an outline in acting to achieve predetermined goals. In the process of teaching and learning, strategy can be interpreted as an available pattern of teacher-student activities in the form of teaching and learning activities to achieve the goals that have been outlined. A learning strategy is a plan of action (series of exercises), including using methods and utilizing various resources or forces in learning that are structured to achieve specific goals. In this case, it is the purpose of education (Marbun, 2019). According to Aprida, the purpose of learning is statements about the knowledge and abilities expected of participants after learning (Pane \& Darwis Dasopang, 2017). 
Tafonao et al. | Teacher and Technoloy: Christian Education Teacher Strategies in Implementing OnlineBased Learning in Pandemic Times

So how do Christian Education teachers apply online base learning today? According to Sidjabat, teachers must plan teaching activities (a teaching plan) before the teacher carries out his duties together with students (Sidjabat, 1999). In addition, according to Telaumbanua, teachers must have the ability to operate technology media (Telaumbanua, 2020). Therefore, one of the plans that teachers must consider is to use technology media. Technology is inevitable, so Christian education teachers must learn how to prepare for learning using technology. Technology is one of the support in smoothing the learning process. With technology, Christian Education teachers are more accessible in preparing online education. But there needs to be a strategy that teachers must prepare in teaching online so that the above problems can be appropriately resolved. Although this strategy can not fully solve the problem, it can help children experiencing difficulties in the online learning process. Therefore, teachers must be able to lead the online learning process correctly and adequately, not only to anticipate the problem of using technology in online learning but also to prevent students from misusing the technology, for example, using smartphones and computers (Alfian et al., 2019). By looking at the explanation above, the formula in the writing of this article is what strategy is most appropriately used by teachers in teaching online. With the formulation of the problem, this article aims to see the extent of teachers' effectiveness in teaching online during pandemics.

Many previous studies have discussed Master and Technology: Guru Agama Kristen's Strategy in Implementing Online-Based Learning in Pandemic Times. There are at least three difficulties that teachers face during the Covid 19 pandemic, according to the article "The Existence of Christian Education Teachers in Learning During the Covid 19 Pandemic" (2021), written by Agusthina Siahaya and Jenri Ambarita. Another study, Jarwati and Dewi Priskawati's "Blended Learning: New Normal Learning Solutions for Christian Education in the Era of the Industrial Revolution 4.0"(2021), claims that teachers must continue to improve their grasp of technology because this learning method is still in its infancy. Furthermore, according to Abraham Tefbana and A. Danny Kia's research, "Improving the Performance of Christian Education Teachers in the Era of Disruption and Pandemic" (2020), one of the strategies for improving the ability and performance of education teachers Agama Kristen in the era of disruption and pandemics is through seminars, training, courses, and further study. Next is the research of Masda Engkol et al., "Christian education Learning Strategy by Teachers during the Covid 19 Pandemic" (2021), which proposes that teachers should carefully prepare learning methods to attract the concentration of students to learn. The five researchers above aim to 
Tafonao et al. | Teacher and Technoloy: Christian Education Teacher Strategies in Implementing OnlineBased Learning in Pandemic Times

encourage Christian education teachers to prepare learning strategies during pandemics. Still, this study has not detailed what teachers do concerning systems in implementing online-based learning (the concept of the study is still general). Therefore, the author examined this topic to elaborate on Christian education teachers' practical things in online teaching and complete the previous studies. The author realizes that writing has shortcomings in narrative, content, and sources not far from existing research.

\section{METHODS}

A descriptive qualitative research method was adopted in this work. Data for qualitative descriptive research is gathered from various credible sources, such as reference books (literature) on the topic at hand. (Gunawan, 2013). Researchers get data through literature studies, empirical data and trace the scientific work of previous researchers that have been published related to the theme of the study. Using literature, researchers collect data by studying reliable journals, articles, books, and scientific papers (not in the form of numbers). Then the researcher analyzes the data and describes it through data analysis techniques with several stages, namely reducing data, classifying and verifying data related to the study of this article.

\section{RESULTS AND DISCUSSION}

The running of learning during pandemic times depends on each teacher's strategy and mastery of informatics technology. But according to the author's savings in supporting teachers' methods, teachers can not be separated from educators' readiness, parents of students, curriculum, availability of learning resources, and stable network support so that communication between learners and educators can be effective. Online education requires the readiness of all stakeholders, predominantly Christian educators. Furthermore, by definition, online learning requires the assistance of qualified technology tools that are easily accessible. Salsabila et al. claimed that the deployment of online learning during a pandemic could not be divorced from technological support since technology can address all of the needs associated with the learning process (Hanifah Salsabila et al., 2020). But the problem is that not all teachers can master technology to the fullest.

Agree disagrees with the average teacher who currently does not have a background in Technology Science (IT). In research conducted by Abdul Syukur, almost all elementary-high school teachers in mastering and implementing Information and Communication Technology 
Tafonao et al. | Teacher and Technoloy: Christian Education Teacher Strategies in Implementing OnlineBased Learning in Pandemic Times

(ICT) in the process of education are still not optimal (Abdul Syukur, 2014). Tambunan also criticizes that learning technology will be effective if it is in the hands of teachers who have adequate levels of digital literacy or vice versa become a problem when in the hands of teachers who are not popular with technology. The basis of his argument is to judge that technology seems to be used in pedagogical needs but is not yet a beneficial and high-quality thing following the world of students in school (Tambunan, 2020). And even more surprising in the writings reported by Nurhayat taken from various research results and papers explained that about 70 to $90 \%$ of teachers are still considered stuttering technology in the utilization of ICT advances in the learning process (Nurhayat, 2016). Darmawan sees this as very sad and even painful. Amid the buzzing of interactive learning (e-learning), teachers are still not maximal in using information technology (Darmawan, 2013). By revealing the various problems and studies of the researchers above, this paper outlines some of the strategies that must be done by Christian education teachers in implementing the process of learning based on online in the pandemic period, namely:

\section{Learning teachers provide features that are easily accessible to students}

One strategy that Christian education teachers do in teaching online during pandemics is that teachers provide features. This feature makes it very easy for teachers and students to send and access various learning materials. Several components must be provided by Christian education teachers in teaching online, namely (1) Google Meet. Google Meet is one of the advocates supporting teaching and learning activities during pandemics; (2) Google Assignments. Google Assignments has a function to manage learning distributed by teachers and analyzes and assesses student assignments more easily and quickly; (3) Classroom. The classroom is conducive to the management of classes and can improve classroom creation and help teachers check student tasks.

With teachers utilizing the features and technological media above, the learning taught to learners can run well. In research conducted by Fauzi said teachers should learn to use online-based learning media during pandemics even if students are at home (Fauzi, 2020). Therefore, teachers are required to stay creative using technology as a means in the learning process. However, the use of technology in the teaching and learning process becomes one of the challenges that are not quickly faced by all parties (Tafonao \& Saputra, 2021). The authors assert that there is no reason for any teacher not to utilize technology as a means of teaching during a pandemic. In addition, if the teacher is in union with the technology media, this is one 
Tafonao et al. | Teacher and Technoloy: Christian Education Teacher Strategies in Implementing OnlineBased Learning in Pandemic Times

form of pedagogy. Iskandar cited Law No. 14/2005 article 1; paragraph 1 "teacher is a professional educator with the main task of educating, teaching, guiding, directing, training, assessing, and evaluating learners on early childhood education, formal education pathways, primary education, and secondary education (Iskandar, 2018). Therefore, one of the essential demands as a professional teacher, namely, teachers must be integrated with the technology media in carrying out their duties as educators. According to frugal Tafonao, Saputra, and Rosita, using technology media in learning is one of the competencies of a teacher as the primary determinant in the learning process (Tafonao et al., 2020).

\section{Teachers learn to design online learning}

Almost all teachers claim that online learning is not as effective as direct face-to-face learning activities because teachers see that the teaching is explained to students online is not necessarily understandable. So do not be surprised if teachers give many independent tasks to students because there is no other way to be taken. The research conducted by Samosir and Boiliu, who proposed several designs of Christian education learners that teachers must do during the pandemic period, suggests that teachers should create a learning model that can attract students' attention rather than simply watching. For example, Whatsaap, google meet, google classroom; (2) create creative and exciting materials through power points and animations to facilitate students' learning; (3) create material explanatory videos; perform virtual classes through zoom and create youtube. After analyzing the three points above, $50 \%$ of students understand the learning material, while $50 \%$ of students cannot understand and explain the material delivered by the teacher (Samosir \& Boiliu, 2021). This means that the design of Christian education learning materials carried out by teachers during the period of emigrants is still not maximal and effective.

Even so, the results of this research that has not been maximal do not mean teachers stop innovating in meeting the needs of students during online learning; Still, until now, Christian teachers are required to continue to strive in designing effective online learning. In response, the author proposes several essential steps that Christian education teachers must take in creating learning during the pandemic, namely (1) teachers must utilize appropriate online devices or media and by the material taught; (2) the teacher prepares for planned online learning; (3) The teacher keeps the students concentrated; (4) Teachers encourage parents to be active in marginalizing children during online learning; (5) Teachers create interactive learning methods. According to frugal Banoet and Tangkin, what is done by the 
Tafonao et al. | Teacher and Technoloy: Christian Education Teacher Strategies in Implementing OnlineBased Learning in Pandemic Times

teacher above is a way to show the ability to benefit from various technological media (Banoet \& Tangkin, 2021). Furthermore, Siahaya and Ambarita propose that Christian Education can design engaging learning and motivate learners and be active and creative in creating and developing teaching materials or learning media that can be used to achieve Christian Education's learning goals. previously (Siahaya \& Ambarita, 2021). In other words, online learning can provide a broader opportunity to explore the material taught to learners.

\section{Teachers get used to providing stimulus to learners}

In addition to teachers mastering and designing learning technologically, teachers must also provide stimulus to learners. Usually, this activity is only face-to-face learning, but the author argues that teachers can use online stimulation to motivate learners. It is also stated by Mansyur stimulus is a teaching activity in the context of the learning interaction process to overcome the boredom of learners. In the process of learning situations, they always show perseverance and full participation. (Mansyur, 2017). In addition, Djamal and Fachrudin said stimulus is a medium in interacting and generating an audience response, namely learners. (Djamal \& Fachrudin, 2011). The interaction between giving (teachers) stimulus and the response (students) gives learners new experiences when doing the learning process at home independently during this COVID-19 period. Therefore, in awakening the independence of learning students in the house of pandemic flu, there are several things that Christian education teachers, namely, must do: (1) the teacher explained the purpose of practical defense to learners; (2) give gifts; (3) The teacher gives time to the learners to present their work through zoom meetings; (4) The teacher gives praise; (5) The teacher provides motivation.

With strategies or approaches like this, it invites the attention of every learner at home to keep learning so that learners do not feel bored even if the learning is done online / distance. But please note together, learning materials must be accessible anytime and anywhere through e-learning. One of the advantages of independent learning is that learners can better think and complete every task educators give. In other words, one way to integrate knowledge through technology learning is to make it easier for learners to learn (Jarwati \& Priskawati, 2020). By looking at these aspects, there is no reason for educators not to provide stimulus to learners so that learning goals can be achieved to the maximum.

In addition to the above, teachers should create interactive learning methods. Not only can face-to-face learning be made fun of, but online learning must be made fun. One way is 
Tafonao et al. | Teacher and Technoloy: Christian Education Teacher Strategies in Implementing OnlineBased Learning in Pandemic Times

that every teacher entering the classroom must create an interactive quiz to become active in education. Every child must have competitiveness to compete to answer the examination given. In the author's experience, not only done with quizzes but need to look for interactive videos on YouTube related to learning materials so that learners attract attention to ask and agree with what they see and observe through the impression so that saturation in learning online can be appropriately resolved. According to Muna and Aziz, online learning models like this can help students think, express ideas, and talk (Muna \&Aziz, 2021).

\section{CONCLUSION}

Based on this study, the authors say that teaching in pandemics requires the right strategies to support the online learning process. Despite all the shortcomings of educators, especially in the mastery of technology, it is not a reason for Christian education teachers not to try and adapt to technological developments. Therefore, through this study, the authors give a new insight to every Christian education teacher to create strategies that can overcome all limitations in teaching online in times of pandemic. Christian education teachers must be creative, innovative, communicative, and give attention and motivation to learners through learning that is being taught to learners. In other words, the purpose of writing this article is very effective every strategy used by the teacher, if it is done with a new paradigm as explained in this article. This paper is here to contribute new thinking to Christian education teachers in carrying out their duties during pandemics and a reference for researchers and education practitioners in looking at various phenomena that occur today in the world of education in the pandemic period.

\section{REFERENCES}

Abdul Syukur, I. (2014). Profesionalisme Guru dalam Mengimplementasikan Teknologi Informasi dan Komunikasi di Kabupaten Nganjuk. Jurnal Pendidikan Dan Kebudayaan, 20(2), 200-210. https://doi.org/10.24832/jpnk.v20i2.138

Alfian, S, D. L., Purba, B. M. M., \& Hutapea, H. (2019). Pentingnya Pendidikan Agama Kristen Di Sekolah Mengantisipasi Kecanduan Smartphone Bagi Anak Kelas 6 Di Sekolah Dasar Theodore Batam. Real Didache, 4(1).

Banoet, A. E., \& Tangkin, W. P. (2021). Tantangan Guru Kristen Dalam Mendidik Karakter Siswa Melalui Pendidikan Karakter Pada Pembelajaran Daring. PEADA' : Jurnal Pendidikan Kristen, 2(1), 72-84. https://doi.org/10.34307/peada.v2i1.32

Basar, A. M. (2020). Problematika Pembelajaran Jarak Jauh Pada Masa Pandemi Covid-19. Edunesia: Jurnal Ilmiah Pendidikan, 2(1), 207-219. https://doi.org/10.51276/edu.v2i1.112

Darmawan, D. (2013). Pendidikan Teknologi Informasi dan Komunikasi. Remaja Rosdakarya.

Djamal, H., \& Fachrudin, A. (2011). Dasar-Dasar Penyiaran: Sejarah, Organisasi, Operasional dan Regulas. Kencana.

Fauzi, M. (2020). STRATEGI PEMBELAJARAN MASA PANDEMI COVID-19. Al-Ibrah, 2(2), 120-145.

Gumitri, A., \& Eliza, D. (2021). Dampak Covid-19 Terhadap Prestasi Belajar Anak di Sekolah. Jurnal 
Tafonao et al. | Teacher and Technoloy: Christian Education Teacher Strategies in Implementing OnlineBased Learning in Pandemic Times

Pendidikan Tambusai, 5(3), 6955-6957.

Gunawan, I. (2013). Metode penelitian kualitatif : Teori dan praktik. BumiAksara.

Hanifah Salsabila, U., Irna Sari, L., Haibati Lathif, K., Puji Lestari, A., \& Ayuning, A. (2020). Peran Teknologi Dalam Pembelajaran Di Masa Pandemi Covid-19. Al-Mutharahah: Jurnal Penelitian Dan Kajian Sosial Keagamaan, 17(2), 188-198. https://doi.org/10.46781/al-mutharahah.v17i2.138

Iskandar, D. (2018). Implementasi Kompetensi Profesional Guru Dalam Meningkatkan Motivasi Belajar Peserta Didik. Journal of Management Review, 2(3), 261-270. https://doi.org/10.25157/jmr.v2i3.1804

Jarwati, \& Priskawati, D. (2020). Blended Learning : Solusi Pembelajaran New Normal Untuk Pendidikan Agama Kristendi Era Revolusi Industri 4.0. Jurnal Pendidikan DIDAXEI, 1(2), 103-113.

Mansyur. (2017). Keterampilan Dasar Mengajar Dan Penguasaan Kompetensi Guru. E-Lghiroh, XII(1), 3355.

Marbun, P. (2019). Strategi Pembelajaran Transformatif. Diegesis: Jurnal Teologi, 4(2), 41-49. https://doi.org/10.46933/dgs.vol4i241-49

Muna, F., \& Aziz, I. N. (2021). Mastering Students' Speaking Skill using Inquiry Online Project-based Strategy. Indonesian Journal of Instructional Media and Model, 2(2), 1-8. https://doi.org/10.32585/ijimm.v3i1.984

Nurhayat, T. (2016). Problematika Guru dalam Menguasai TIK (Teknologi Informasi dan Komunikasi) Pada Pembelajaran Pendidikan Agama Islam dan Solusinya di MI Al-Asy'ari Kuniran Batangan Kabupaten Pati Tahun Ajaran 2015/2016. Universitas Islam Negeri Walisongo Semarang.

Pane, A., \& Darwis Dasopang, M. (2017). Belajar Dan Pembelajaran. FITRAH:Jurnal Kajian IImu-IImu Keislaman, 3(2), 333. https://doi.org/10.24952/fitrah.v3i2.945

Prawanti, L. T., \& Sumarni, W. (2020). Kendala Pembelajaran Daring Selama Pandemic Covid-19. Prosiding Seminar Nasional Pascasarjana UNNES, 286-291.

Safitri, N. G., Zulfa, A., Cristanti, A., Wulandari, P. R., \& Islami, E. N. (2020). Dampak Pandemi Covid-19 Terhadap Penerapan Pembelajaran Daring di Sekolah Dasar (Vol. 1).

Samosir, C. M., \& Boiliu, F. M. (2021). Pembelajaran Pendidikan Agama Kristen Berbasis Daring di Masa Pandemi Covid 19. Jurnal Basicedu, 5(4), 2156-2163.

Siahaya, A., \& Ambarita, J. (2021). Eksistensi Guru Pendidikan Agama Kristen Dalam Pembelajaran Di Tengah Pandemi Covid 19. EDUKASI: Jurnal Penelitian Pendidikan Agama Dan Keagamaan, 19(1), 67-84. https://doi.org/10.32729/edukasi.v19i1.851

Sidjabat, B. S. (1999). Strategi Pendidikan Kristen Suatu Tinjauan Teologis-Filosofis. Andi Offset.

Situmorang, K., Lahagu, A., \& Purba, B. M. M. (2019). Peran Guru Pendidikan Agama Kristen Dalam membentuk Karakter Siswa. Real Didache, 4(2).

Tafonao, T., \& Saputra, S. (2021). TEKNOLOGI DAN COVID: Tantangan dan Peluang dalam Melaksanakan Pembelajaran Daring di Masa Pandemi. Djtechno: Journal of Information Technology Research, 2(1), 45-53.

Tafonao, T., Saputra, S., \& Suryaningwidi, R. (2020). Learning Media and Technology: Generation Z and Alpha. Indonesian Journal of Instructional Media and Model, 2(2), 89-100. https://doi.org/10.32585/ijimm.v2i2.954

Tambunan, E. (2020). TEKNOGOGI: Model Pembelajaran Baru dan Masyarakat Kota. Jurnal Shanan, 4(2), 108-127.

Telaumbanua, A. (2020). Implementasi Pendidikan Agama Kristen di Era Tekonologi. Sanctum Domine: Jurnal Teologi, 9(2), 49-64. https://doi.org/10.46495/sdjt.v9i2.67

Utomo, K. D., Soegeng, A. Y., Purnamasari, I., \& Amaruddin, H. (2021). Pemecahan Masalah Kesulitan Belajar Siswa pada Masa Pandemi Covid-19. Mimbar Pgsd Undiksha, 9(1), 1-9. 